\title{
MODEL PEMBERDAYAAN SANTRI PONPES AL-HIDAYAH BATU MALANG SEBAGAI KADER KESEHATAN BERBASIS TERAPI HERBAL
}

\author{
Yoyon Arif Martino, Erna Sulistyowati, Yudi Purnomo \\ 1)Unit pengabdian kepada Masyarakat Fakultas Kedokteran Unisma \\ email: yoyonariff@gmail.com \\ 2)Unit pengabdian kepada Masyarakat Fakultas Kedokteran Unisma \\ email: ernakertosono@yahoo.co.id \\ 3)Unit pengabdian kepada Masyarakat Fakultas Kedokteran Unisma \\ email: ypurnomo31@yahoo.com
}

\begin{abstract}
ABSTRAK
Pendahuluan Fakultas Kedokteran Unisma mempunyai visi dan misi mengembangkan pemanfaatkan keanekaragaman hayati sebagai pengobatan komplementer. Salah satu program perwujudan visi dan misi adalah kegiatan pengabdian masyarakat berupa pemberdayaan santri pondok pesantren (PP) Al Hidayah Batu, Malang sebagai kader kesehatan berbasis terapi herbal. Pondok ini memiliki santri dhuafa usia anak sekolah. Mereka diasuh, dibina dan mendapat pendidikan formal, ilmu agama dan keterampilan pekerjaan. Berdasarkan analisis kekuatan, kelemahan, peluang, dan hambatan, maka solusi permasalahan pelayanan kesehatan santri adalah pelatihan santri sebagai kader kesehatan berbasis terapi herbal. Metode Kegiatan meliputi ceramah, demonstrasi dan praktek. Materi kegiatan yakni jenis tanaman herbal berkhasiat obat, budidaya tanaman herbal dan meracik tanaman herbal sebagai obat. Evaluasi dilakukan pada setiap tahapan; pre dan post test, seperti tingkat kehadiran peserta, materi pelatihan yang tersajikan, persentase peserta yang menguasai materi dan tingkat penguasaan materi. Hasil Santri PP Al Hidayah antusias mengikuti kegiatan ini. Evaluasi kegiatan mencapai target, antara lain tingkat kehadiran peserta, materi pelatihan yang tersajikan, prosentase peserta yang menguasai materi dan tingkat penguasaan materi pelatihan $(\geq 80 \%)$. Tujuan kegiatan tercapai dan mendapatkan respon yang baik. Tindak lanjut kegiatan yakni peningkatan kemandirian santri dalam budidaya tanaman herbal dan meraciknya untuk mengatasi penyakit secara mandiri serta menjaga kebersinambungan kegiatan pada periode berikutnya. Kesimpulan Model pemberdayaan santri pondok pesantren sebagai kader kesehatan berbasis terapi herbal dapat dijadikan contoh sebagai pelayanan kesehatan tradisional pada komunitas santri.
\end{abstract}

Kata kunci: Model Pemberdayaan Santri, Kader Kesehatan, Herbal

\section{Pendahuluan}

Pondok Pesantren (PP) Al-Hidayah I dan II Kec. Batu Kota Batu Malang merupakan pondok pesantren besar dengan jumlah santri yang secara keseluruhan merupakan anak dari kaum dhuafa yang berjumlah lebih kurang 250 santri yang terdiri atas santri laki-laki dan perempuan. Jenjang pendidikan yang ada di lingkungan PP Al Hidayah I dan II antara lain Madrasah Ibtida'iyah,

Madrasah Tsanawiyah dan Madrasah Diniyah. Seluruh santri PP Al Hidayah adalah santri dhuafa dimana orang tua mereka tidak mampu memberikan pendidikan formal bagi anak-anaknya. Ponpes Al Hidayah 
membentu memberikan pendidikan gratis bagi mereka yang tidak mampu tanpa memandang perbedaan. Pendidikan di lingkungan PP Al-Hidayah selain mendidik ilmu agama juga membekali keterampilan kepada para santriwan dan santriwati untuk bekal jika kelak telah kembali ke masyarakat bisa memanfaatkan ilmu di pondok pesantren guna pembangunan masyarakat dimana santri tersebut kembali. PP Al-Hidayah terbagi menjadi tiga PP yakni PP Al-Hidayah I, PP Al-Hidayah II dan PP Al-Hidayah III. PP Al-Hidayah I dan PP Al-Hidayah II merupakan pondok pesantren modern dengan menggabungkan ilmu umum dan ilmu agama Islam di lingkungannya. Sedangkan PP Al-Hidayah III merupakan PP salafiyah, yakni hanya mendidik ilmu agama Islam di lingkungannya.

Pada bidang pelayanan kesehatan, Pesantren An-Hidayah saat ini telah merintis klinik pesantren. Perintisan klinik pesantren ini dimaksudkan untuk melayani kesehatan para santri. Rentang usia santri mulai 6 tahun hingga 23 tahun. Klinik pesantren ini belum tersedianya kelengkapan yang cukup dan tenaga medis yang memadai, membuat klinik ini belum efektif memberikan pelayanan kesehatan seluruh santri Al-Hidayah Batu Malang.

Usaha lain yang dilalukan pesantren dalam upaya memberikan pelayanan kesehatan kepada santrinya adalah dengan dirintisnya kerjasama dengan kementrian kesehatan. Pada bulan Nopember 2008, Pemerintah melalui Kementerian Kesehatan mencanangkan Pos Kesehatan Pesantren (Poskestren). Namun seperti yang sudah diketahui umum, bahwa proyek proyek seperti ini memerlukan dana yang besar dan pelaksanaannya belum tentu lancar seperti yang direncanakan. Terbukti sampai saat ini, keberadaan Poskestren belum sepenuhnya bisa memenuhi kebutuhan santri akan terjaminnya kesehatan. Lagi lagi pesantren Al-Hidayah mengalami kendala dalam melayani kesehatan para santri yang diasuhnya. Dalam dua tahun keberadaan Poskestren Al-Hidayah, dirasakan masih banyak problema yang dihadapi. Kendala lokasi Poskestren yang agak jauh dari pondok $( \pm 1 \mathrm{~km})$ dan terbatasnya waktu pelayanan menyebabkan pelayanan kesehatan belum optimal. Dengan demikian dibutuhkan keberadaan kader kesehatan yang memahami tentang kesehatan dengan memanfaatkan tanaman herbal sebagai penatalaksanaan awal penyakit sebelum dibawa ke poskestren maupun pelayanan kesehatan primer setempat.

Program Pendidikan Dokter Universitas Islam Malang, sejak awal telah memfokuskan diri pada penggalian potensi tanaman Indonesia sebagai tanaman herbal. Beberapa usaha yang dilakukan diantaranya dengan merintis kerjasama dengan balai tanaman obat yang ada di kota Batu dan telah menyusun bank data tentang tanaman obat Indonesia. Selain itu, kegiatankegiatan pengembangan ilmu diarahkan untuk menggali potensi tanaman obat Indonesia.

Tanaman herbal saat ini menjadi primadona masyarakat karena adanya gejala "back to nature" dan tingginya biaya pengobatan.

Kandungan senyawa Antioksi dan dalam beberapa herbal dapat digunakan 
untuk menangkal radikal bebas yang berefek buruk bagi kesehatan. Beberapa penyakit seperti Kanker, Aterosklerosis, Diabetes Mellitus, Penyakit Paru Obstruktif Menahun (PPOM) timbul akibat keberadaan radikal bebas berlebih dalam tubuh. Konsumsi buah, sayuran, dan herbal kaya antioksidan diharapkan mampu untuk menetralisir serangan radikal bebas yang bertubitubi masuk ke dalam tubuh sehingga gangguan kesehatan dapat dihindari .

Herbal selain diolah sebagai ramuan obat-obatan, dapat pula dipakai makanan yang menyehatkan. Salah satu pengolah tanaman herbal ini menjadi makanan adalah pengrajin (home industry) kerupuk dan minuman herbal.

Program Pendidikan Dokter Universitas Islam Malang (Unisma) merupakan Fakultas Kedokteran pertama di lingkungan Nadliyin. Visi Pendidikan Tinggi di Kedokteran Unisma menjadi salah satu Fakultas Kedokteran terkemuka dalam pendidikan kedokteran dan pengembangan ilmu pengetahuan dan teknologi kedokteran/kesehatan (Iptekdokkes) khususnya dalam pemanfaatan keanekaragaman hayati sebagai penunjang pengobatan dan berazaskan keislaman. Sedangkan misi pendidikan ini yakni mendidik calon dokter profesional yang mampu mengembangkan dan mengabdikan Iptekdokkes khususnya pemanfaatan keanekaragaman hayati untuk menunjang pengobatan. Selain itu mendidik mahasiswa agar bisa menjadi katalisator dalam pengembangan usaha industri yang terkait dengan keanekaragaman hayati yang menunjang pengobatan.

Melihat kemampuan yang dimiliki Program Pendidikan Dokter Universitas Islam Malang dengan visi dan misi pemanfaatan keanekaragaman hayati dan potensi tanaman herbal seperti yang dipaparkan di atas, maka ada peluang untuk membantu memecahkan permasalahan yang dihadapi oleh Pondok Pesantren Al-Hidayah Batu Malang. Didukung dengan misi dan visi baik dari Universitas Islam Malang pada umumnya maupun Program Pendidikan Dokter pada khususnya yakni pembinaan masyarakat pesantren dalam hal ini bidang kesehatan.

Berikut diuraikan mengenai permasalahan mitra. Bagian Kesehatan Pondok Pesantren Al-Hidayah I dan II mencatat ada sepuluh penyakit terbanyak di lingkungan pondok. Dari yang terbanyak yakni Infeksi Saluran nafas atas (influenza), Penyakit kulit infeksi dan alergi (termasuk skabies, bisul, infeksi jamur), gangguan pencernaan (termasuk gastritis, diare, typhus) dan penyakit rongga mulut. Santri mengalami kesulitan dalam memberi penanganan awal karena kurangnya pemahaman kesehatan dan penatalaksanaan awal sebelum dibawa ke pos kesehatan pesantren. Bahkan di lingkungan kamar santri terdapat wabah kutu busuk yang menyerang hunian kamar para santri. Berbagai upaya telah dilakukan untuk membasmi serangga tersebut. Akibatnya banyak pula santri yang menderita gatal akibat digigit kutu busuk tersebut. Untuk mencari solusi dari permasalahan ini ada baiknya untuk melihat kembali secara lebih rinci tentang kekuatan, kelemahan, peluang, dan hambatan yang ada di Pondok Pesantren Al- 
Hidayah, Khususnya Pesantren Al-Hidayah I dan II Batu Malang dalam hal memberikan pelayanan kesehatan kepada santrinya.

Tabel 1.

Analisis SWOT program pengabdian masyarakt di Ponpes Al-Hidayah Batu Malang

\begin{tabular}{ll}
\multicolumn{1}{c}{ Kekuatan } & \multicolumn{1}{c}{ Kele mahan } \\
\hline - Jumlah santri yang cukup banyak (hampir 250 orang) \\
$\begin{array}{l}\text { yang keseluruhan adalah kaum dhuafa yang dibina } \\
\text { untuk mendapatkan pendidikan layak. }\end{array}$ & $\begin{array}{l}\text { Tidak memiliki tenaga yang memiliki kemampuan } \\
\text { di bidang medis }\end{array}$ \\
\hline $\begin{array}{l}\text { Jumlah guru yang memadai (25 orang selain guru dari } \\
\text { luar) }\end{array}$ & $\begin{array}{l}\text { Tidak memiliki tenaga yang memiliki kemampuan } \\
\text { dan pengetahuan dalam budidaya tanaman } \\
\text { herbal. }\end{array}$ \\
\hline
\end{tabular}

- Jumlah lahan pesantren yang sekitar 5 hektar dan

sebagian besar masih tanah kosong.

\begin{tabular}{ll}
\multicolumn{1}{c}{ Peluang } & \multicolumn{1}{c}{ Hambatan } \\
\hline $\begin{array}{l}\text { Peluang untuk membudidayakan tanaman herbal } \\
\text { sebagai tanaman obat di lahan yang ada untuk menjaga } \\
\text { kesehatan para santri }\end{array}$ & $\begin{array}{l}\text { Kesadaran akan pentingnya perawatan } \\
\text { kesehatan di kalangan santri masih rendah. }\end{array}$ \\
\hline $\begin{array}{l}\text { Potensi tanaman herbal untuk diolah menjadi makanan } \\
\text { yang menyehatkan dan bernilai ekonomis akan } \\
\text { memberikan keterampilan dan bekal berwirausaha } \\
\text { kepada santri kelak di masyarakat. }\end{array}$ & $\begin{array}{l}\text { Kemampuan para santri dan pengurus pesantren } \\
\text { dalam membudidayakan tanaman herbal dan } \\
\text { mengolahnya masih rendah. }\end{array}$ \\
\hline
\end{tabular}

\section{Permasalahan}

Bagaimana meningkatkan pelayanan kesehatan terhadap santri pondok pesantren dhuafa $\mathrm{Al}$ Hidayah I dan II Batu Malang dengan memanfaatkan potensi yang dimiliki

\section{Alternatif Solusi}

1. Pesantren mendirikan klinik kesehatan untuk melayani kesehatan para santri

2. Pesantren bekerjasama dengan pemerintah mendirikan balai pengobatan untuk pelayanan kesehatan pesantren

3. Mendidik tenaga medis dari kader pesantren yang nantinya dapat melayani kesehatan di lingkungan pesantren.

4. Perguruan tinggi melaksanakan salah satu Tri-darma Perguruan Tinggi bidang pengabdian kepada masyarakat berupa pendampingan dan pembimbingan dalam upaya upaya pelayanan kesehatan.

Berdasarkan Tabel 1 tersebut, alternatif solusi pertama telah dilaksanakan dan tidak berjalan disamping karena menuntut sumber daya yang cukup besar juga karena faktor faktor penghambat lainnya. Alternatif kedua juga bukan merupakan hal mudah dan telah terbukti tidak bisa berjalan lancar. Alternatif ketiga memerlukan waktu lama dan biaya yang cukup besar. Alternatif yang terakhir merupakan solusi yang lebih efektif dan efisien yang berdampak dalam jangka panjang serta lebih profesional disamping pula dapat tetap menjaga hubungan baik perguruan tinggi dengan komunitas 
masyarakatnya dalam hal ini pondok pesantren Al-Hidayah I dan II Batu Malang.

Berdasarkan analisis situasi di atas, maka masalah yang dapat dirumuskan sebagai berikut;Pondok Pesantren Al-Hidayah I dan II di Batu Malang menghadapi permasalahan dalam upaya memberikan pelayanan kesehatan kepada para santrinya. Dengan demikian pesantren tersebut memerlukan bantuan untuk mewujudkan upayanya memberikan pelayanan kesehatan yang memadai dan mandiri kepada para santrinya, disamping itu memberikan bekal aspek kesehatan yang akan berguna pada para santri dan menjadi bekal ketika kembali kemasyarakat.

Ada beberapa alternatif pemecahan masalah, diantaranya adalah:1). Pesantren mendirikan klinik kesehatan untuk melayani kesehatan para santri. 2). Pesantren bekerjasama dengan pemerintah mendirikan balai pengobatan untuk pelayanan kesehatan pesantren. 3). Mendidik tenaga medis dari kader pesantren yang nantinya dapat melayani kesehatan di lingkungan pesantren. Dan 4). Perguruan tinggi melaksanakan salah satu Tri-dharma Perguruan Tinggi bidang pengabdian kepada masyarakat berupa pendampingan dan pembimbingan dalam upaya upaya pelayanan kesehatan.

Pihak pesantren dapat saja mendirikan klinik kesehatan untuk memberikan layanan kesehatan kepada para santrinya, namun cara ini membutuhkan biaya dan sumber daya yang tidak sedikit belum lagi prosedur yang berbelit.

Pesantren bersama pemerintah dapat menggagas suatu balai pengobatan yang beroperasi khusus di pesantren semacam puskesmas pesantren, namun hal ini tentunya memerlukan proses yang lama dan seperti biasanya kegiatan semacam ini hanya sukses diawal awal program kemudian setelah itu terbengkalai.

Pesantren dapat pula membina kadernya sebagai tenaga medis dan kemudian memberikan layanan kesehatan kepada pesantren tersebut, namun hal ini memerlukan investasi yang besar dan waktu yang lama disamping itu ketergantungan terhadap seseorang menjadi layanan tersebut tidak mandiri.

Penerapan IPTEK dari perguruan tinggi berupa pelatihan pembudidayaan dan pengolahan tanaman herbal sebagai obat dan panganan yang menyehatkan bagi para santri dan pengurus pondok/guru Al-Hidayah I dan II merupakan cara yang paling strategis karena bentuk dan materi pelatihan dapat disesuaikan dan disepadankan dengan kebutuhan dan kemampuan pesantren tersebut. Disamping itu dengan adanya kegiatan ini, adanya peningkatan hubungan kemitraan yang baik antara kalangan pesantren dengan perguruan tinggi (disamping kegiatan kegiatan yang sudah ada) yang pada akhirnya berdampak positif bagi kedua institusi.

\section{Metode Kegiatan}

Berdasarkan pada kerangka pemecahan masalah yang telah dirumuskan, pengabdian kepada masyarakat berupa pelatihan budidaya tanaman herbal 
beserta pengelolaan dan pengolahannya menjadi obat dan makanan yang menyehatkan dilaksanakan di lingkungan pesantren dhuafa Al-Hidayah I dan II Batu Malang, dengan pembekalan materi pokok sebagai berikut;1). Jenisjenis tanaman herbal yang berkhasiat antioksidan, 2). Budidaya tanaman herbal, 3). Mengolah tanaman herbal sebagai obat, 4). Mengolah tanaman herbal sebagai panganan yang menyehatkan dan 5). Aspek ekonomis dari olahan tanaman herbal.

Sedangkan metode yang digunakan dalam setiap tahapan pelaksanaan kegiatan penerapan ipteks ini adalah metode ceramah, demontrasi dan praktek. Metode ceramah, metode ini digunakan untuk menyampaikan aspekaspek teoritis dan pernyataan berkaitan dengan tanaman herbal beserta pengolahannya. Selain itu santri dibekali dengan beberapa buku pustaka tentang pemanfaatan tanaman herbal yang berkhasiat obat melalui penambahan koleksi buku di perpustakaan Ponpes. Yang kedua adalah demontrasi. Metode ini digunakan untuk menyampaikan atau mendemokan tata cara bertanam, memelihara, mengelola, dan mengolah tanaman herbal. Yang terakhit metode praktek. Metode ini digunakan untuk memberi bekal pengalaman dan keterampilan bagi peserta pelatihan dalam bertanam, memelihara, mengelola, dan mengolah tanaman herbal yang berkhasiat obat.

Kegiatan ini akan dievaluasi pada setiap tahapan untuk menyempurnakan pada tahapan berikutnya serta untuk mengetahui tingkat pencapaian dari target target yang telah direncanakan. Secara lebih rinci, kegiatan ini akan dievaluasi tingkat keberhasilannya dari beberapa indicator berikut ini beserta target target pencapaiannya.

Tabel 2.

Evaluasi selama pelatihan

\begin{tabular}{lll}
\hline \multicolumn{1}{c}{ Indikator } & Target Pencapaian \\
\hline 1. & Tingkat kehadiran peserta & $\geq 80 \%$ \\
2. & Materi pelatihan yang tersajikan & $100 \%$ \\
3. $\begin{array}{l}\text { Prosentase peserta yang menguasai materi } \\
\text { pelatihan }\end{array}$ & $\geq 40 \%$ \\
4. Tingkat penguasaan materi pelatihan & $80 \%$ tingkat mahir \\
\hline
\end{tabular}

Tabel 3.

Evaluasi Pasca Pelatihan

\begin{tabular}{lll}
\multicolumn{1}{c}{ Indikator } & Target Pencapaian \\
\hline 1. Jumlah santri peserta pelatihan yang menanam & $\geq 80 \%$ \\
herbal & $\geq 80 \%$ \\
2. Tingkat penguasaan keterampilan menanam & $\geq 80 \%$ \\
herbal & $\geq 80 \%$ \\
3. Jumlah santri yang terampil meracik herbal untuk & $\begin{array}{l}\text { Obat } \\
\text { Jumlah lahan herbal yang dialokasikan yang } \\
\text { tertanami }\end{array}$ & \\
\hline
\end{tabular}




\section{Hasil}

Rencana pelaksanaan kegiatan pelatihan selama empat bulan dengan delapan kali tatap muka. Tabel kegiatan dapat dilihat pada Tabel 4 berikut.

Tabel 4.

Rencana Materi Kegiatan

\begin{tabular}{ll}
\multicolumn{1}{c}{ Tanggal } & \multicolumn{1}{c}{ Materi } \\
Pertemuan pertama & Pengenalan Kegiatan \\
Pertemuan kedua & Jenis-jenis Tanaman Herbal dan Khasiatnya \\
Pertemuan ketiga & Jeni-jenis Ramuan Herbal dan Khasiatnya \\
Pertemuan keempat & Budidaya Tanaman Herbal dan Khasiatnya \\
Pertemuan kelima & Meracik Tanaman Herbal dan Khasiatnya \\
Pertemuan keenam & Evaluasi kegiatan
\end{tabular}

Hasil kegiatan sampai dengan laporan kemajuan ini dibuat didapatkan bahwa santri dan para pembina/guru di pesantren Al Hidayah memberikan respon yang baik terhadap kegiatan ini. Kegiatan yang telah dilakukan yakni pemberian materi tentang (1)khasiat berbagai macam tanaman herbal yang ber khasiat obat, (2) materi pengolahan tanaman herbal berkhasiat obat. Dengan demikian didapatkan hasil bahwa sampai dengan pelaporan kemajuan ini dibuat telah mencapai $70 \%$ dari target yang akan dicapai dari kegiatan ini. Peserta baik santri dan guru memberi respon yang baik pada kegiatan ini. Namun kami belum merekapitulasi daftar hadir peserta dan evaluasi kemampuan peserta.

\section{Pembahasan dan Diskusi}

Perguruan Tinggi, dalam hal ini Universitas Islam Malang pada umumnya dan Program Pendidikan Dokter khususnya, yakni sesuai visi dan misinya yakni pemanfaatan keanekaragaman hayati untuk menunjang pengobatan. Untuk itu program pengabdian ini merupakan sarana untuk menerapkan ipteks yang ada dan dikembangkan di perguruan tinggi, sebagai bentuk kepedulian terhadap komunitas akademik di bawahnya, dan sebagai sarana promosi perguruan tinggi.

Dengan demikian institusi Program Pendidikan Dokter di bawah naungan Universitas Islam Malang memberikan pengabdian berupa pelatihan teknologi budidaya tanaman herbal yang dimanfaatkan sebagai ramuan penatalaksanaan penyakit yang banyak diderita santri.

Pemilihan Pondok Pesantren pada Ponpes Dhuafa Al-Hidayah I dan II di Batu Malang, didasarkan pada pengalaman kami sebagai tim kesehatan ponpes. Ponpes yang mengasuh anak-anak dhuafa ini cocok diterapkan sebagai sarana untuk meningkatkan kemampuan dan penguasaan dalam membudidayakan, mengelola, dan mengolah tanaman herbal sebagai ramuan obat dalam penatalaksanaan awal penyakit. Dan ini akan menjadi referensi bagi pesantren pesantren lain atau lembaga pendidikan lainnya yang ada di wilayah Malang khususnya dan di Indonesia pada umumnya. 
Keterkaitan program ini juga berkesinambungan dengan program Dinas Kesehatan dan Kementrian agama, khususnya wilayah kerja Malang dan Jawa Timur, sesuai Surat Keputusan Bersama Menteri Kesehatan, Menteri Agama dan Menteri Dalam Negeri No. 1067/MENKES/SKB/VIII/2002, No. 385 tahun 2002 dan No. 37 tahun 2002 tentang Peningkatan Kesehatan Ponpes dan Instansi Keagamaan lainnya. Dengan kegiatan ini dapat membantu program pemerintah dan mengurangi anggaran untuk pelatihan guru pesantren berkaitan dengan tanaman herbal ini dan mengurangi anggaran dalam menyediakan layanan kesehatan khususnya bagi masyarakat pesantren.

Dengan demikian hasil yang ingin diharapkan dari terlaksananya kegiatan pengabdian ini adalah pertama peningkatan keterampilan santri dhuafa dalam pengelolaan tanaman herbal yang spesifik untuk berbagai jenis penyakit. Kedua peningkatan keterampilan santri membuat ramuan berbagai penyakit yang banyak diderita santri Al-Hidayah. Ketiga metode pelatihan kader kesehatan di lingkungan santri dhuafa terutama dalam pemanfaatan tanaman herbal untuk penatalaksanaan awal penyakit. Keempat metode diseminasi pengetahuan kader kesehatan santri dhuafa kepada generasi berikutnya untuk menjaga kesinambungan kegiatan pelatihan budidaya tanaman herbal dan keterampilan penatalaksanaan awal penyakit. Dengan demikian kegiatan ini berhasil mencapai tujuan dan bisa dijadikan model dalam dapat dijadikan contoh sebagai pelayanan kesehatan tradisional pada komunitas santri.

\section{Ucapan Terimakasih}

Kami menyampaikan terimakasih yang sebesar-besarnya kepada Ditjen Penelitian dan Pengabdian Kepada Masyarakat (DITLITABMAS) Dirjen Pendidikan Tinggi Kementerian Pendidikan dan Kebudayaan atas persetujuan pendanaan kegiatan pengabdian Ipteks bagi masyarakat (IbM) ini. Dengan nomor kontrak 203/SP2H/KPM/DIT.LITABMAS/V/2013.

\section{DAFTAR PUSTAKA}

BPOT (Badan Pengawasan Obat dan Tanaman). (2010). Materi Saresehan Herbal berkhasiat Obat. Tawangmangu. Karanganyar, Surakarta.

Dinas Kesehatan Propinsi Jawa Timur. (2008) Materi Pelatihan Pos Kesehatan Pesantren (Poskestren).

Pramono, K. (2006). Tingkat Manfaat dan Keamanan Tanaman Obat dan Obat Tradisional. Balai Penelitian Obat Tawangmangu. Fakultas Farmasi UGM. Yogyakarta

Tukiman. (2004). Pemanfaatan Tanaman Obat Keluarga untuk Kesehatan Keluarga. Bagian Pendidikan Kesehatan dan IImu Perilaku Fakultas Kesehatan Masyarakat Universitas Sumatera Utara. Medan.

Zein, Umar. (2005). Pemanfaatan Tanaman Obat dalam Upaya Pemeliharaan Kesehatan. Divisis Penyakit Tropik dan Infeksi. Bagian Ilmu Penyakit Dalam Fakultas Kedokteran Universitas Sumatera Utara. Medan 